\title{
Competitive Advantage Through Positioning Strategy ith Indirect Effects: Study Of Outlet Business In Rest Area Jakarta-Cikampek Toll Road West Java Indonesia
}

\author{
Joseph M.J.Renwarin \\ Institut Teknologi dan Bisnis Kalbis Jakarta \\ Email: joseph.renwarin@kalbis.ac.id
}

\begin{abstract}
.
The objective of this paper is give analysis about current condition of businesses in rest area at toll road in the West Java. The destination of toll road divided by two point, the first, to Bandung city through access to center Java by south Java island route and the second, to Cirebon city through access to center Java by north Java island route. The impact of the open new access is have many opportunities business in the rest area. Every business owner and management try to create the best strategies for sustain by the increase of revenue. Starbuck is one of the sucsess outlets in that. Therefore, this research try to find the impact of importance, communicability and affordability on customer purchase decision. The methodology of this research is exploratory research with the object of research is the customers of Starbuck outlet in rest area KM 19 as the respondents. The datas collecting from focus group discussion (FGD), some interviews to manager, questionare disbursement. The results of research are the influence purchasing decisions at point of $r$ table numbers $R$ of 0.639 is obtained. The communicability is the big influential variable on customer purchase decision.
\end{abstract}

Keywords: Positioning Strategy. Rest Area Business, Importance, Communicability, Affordability, Purchase Decision.

\section{INTRODUCTION}

The phenomena development of the world society could impact to Indonesia society, like the changing of life style, etc. Indonesia position in global economic in $16^{\text {th }}$ rank. Fourty five million people in the midle class and $53 \%$ of the population in the cities which were support of $74 \%$ of Gross National Product (McKinsey Global Institute, 2014). Indonesia have been changing in business environment. In 1997 - 2000, all the business focus on layoffs, down economy condition and corporate consolidation but in 2001 - 2013, the condition to economic growth, business expansion and global competition and business change (Mahardika, 2015). The trend of change of world community lifestyle have impact to Indonesia people and it have been grown phenomenon. As a result of the expansion of the food industry which is manifested in the form of fastfood restaurants. Shifts and lifestyle changes significantly affect the lifestyle of the instant with the consumer behavior and consumerism. The culture of drinking coffee that has become the trend of the urban lifestyle in Indonesia, especially in Jakarta in the last 15 years. This trend is not only as a coffee drinker, but also switching to other segments, which become coffee connoisseurs. In addition to relieving sleepiness caffeine in coffee is basically also serves as aspirin or pain relieving drugs. Coffee is also good for the body as it includes antioxidants that serves to maintain immunity or immune system by pressing the cell damage that occurs as a result of the oxidation process that causes of free radical (kopistory, 2015). Now on, the coffee function has evolved from health to become phenomenon of the urban lifestyle. They make a tradition of drinking coffee as a means of socializing with relaxed chatting with friends, relatives and business discussion with colleagues at the coffee shop. The location of coffee outlet has become same as important of the coffee itself. The exclusive outlet is now flourishing in Jakarta, with wide variety of designs and include additional amenities and atmosphere made as comfortable as possible so that visitors linger to enjoy coffee and other support offerings. The Starbucks is one of the international retail coffee shops wich are blossoming in Indonesia and especially 
Jakarta city. The business opportunities coffee shop in Jakarta is still promising, so it is not surprising now the coffee shop is easy to find. It is probable that these outlets will be growing because Jakarta is one of the potential business city with more than 9 million inhabitants recorded in 2010 based on data from the Central Statistics Agency of Jakarta. In addition to the drive-in service concept, Starbucks outlets in the rest area also still provide other facilities such as the concept of the mall and offices. The rapid development of the business concept in rest area tollroad will certainly create close-fitting competition. The competition not only with other companies, but competition can also occur among Starbucks stores that are in the direction of travel. In the face of competitive conditions, Starbucks conduct appropriate marketing strategy for one of the purposes of maintaining consumer confidence in order to have stability and positioning as a brand that is always remembered by costumers. The owner and founder of Starbucks, Howard Schults, committed with the vision to build a company that is humane. According to him, Starbucks is not in the coffee business serving people, but in the people business serving coffee (Yuniasari S. D. 2009 p. 10). In his working visit to Jakarta on April 4, 2013, Schultz said that the company's key to success was love and humanity, which was not lead into in books and classes of any business. This two things that Starbucks could collaborate with customers, employees and coffee suppliers. In addition, in running a business, there were successed that have been experienced by Starbucks and it was 'trust' (tempo magazine, 2013). Starbucks outlet in rest area with the drive-in concept was opened in 2005, at KM19 Cikampek Toallroad. The veracious location because of high traffic made Starbucks outlets in locations KM 19 became one of the company's flagship.

\begin{tabular}{cc}
\hline Year & Sales in IDR \\
\hline 2009 & $6,864,158,864.00$ \\
\hline 2010 & $7,358,877,320.00$ \\
\hline 2011 & $7,360,010,298.00$ \\
\hline 2012 & $7,979,286,288.00$ \\
\hline 2013 & $8,378,250,602.40$ \\
\hline 2014 & $8,797,163,132.52$ \\
\hline 2015 & $9,237,021,289.15$ \\
\hline 2016 & $9,698,872,353.60$ \\
\hline 2017 & $10,183,815,971.28$ \\
\hline
\end{tabular}

Source: Author calculation for Starbuck Rest Area KM 19 west Java

These data look likes that in the face of the storm of trade and industry crisis hit Indonesia in the years 2007 2008, but the sales of Starbuck at KM 19 continues to increase. Starbucks in the rest area KM 19 always maintains positioning on purchasing decisions by customers in a competitive rivalry among companies large and small coffee shops and restaurants in the vicinity that have similar products. Competitors include Kentucky Fried Chicken (KFC), Dunkin Donuts, Nescafe, Pizza Hut, Holland Bakery and Star Mart. In 2015, Starbucks has 12 outlets spread across several rest areas in Cikampek Toallroad West Java (starbucks, 2016). The presence of a reputable outlets also affect of the sustainability of the management of the rest area The customers need and want of rest area are toilet, rest rooms, eating and coffee. Sometimes, just relaxing with smoking lazy. The moving and changing of lifestyle behavior in rest area could be the significant impact for instant behavior such as instant consumerism behavior. The questions of the behavior changing for the rest area management as follows : 
1. The customers visit in rest area is because of relaxing or some purposes ?

2. Have the tenants been more attractives?

3. Did the international tenants gave effects?

4. Did the outlet brand influence to rest area ?

5. What are the strategies of outlet management in rest area ?

Considering the location, according to the Starbucks Store Manager's opinion and other conformities in the research process, the product attributes to be studied are only the variables of importance, communicability and affordability because these variables conform the situation of Starbucks outlet in the KM 19 rest area. Thus, in this study the problems can be formulated as follows:

- Does the variable of importance influence the customer puchase decision?

- Does the variable of communicability influence the customer puchase decision?

- Does the variable of affordability influence the customer puchase decision?

- Do the variables of importance, communicability, and affordability simultaneously influence the customer puchase decision?

- Which variable is the most influential to the customer puchase decision?

\section{LITERATURE REVIEW}

To implement a positioning strategy, it can be determined based on the attributes of product, benefit, application \& using, user, competitor, product category, and price. However, the concept of product attribute is one base to determine the marketing concept as well the subsequent activities like production, marketing, and distribution. Positioning is part of bundle of customers benefits (Ghosh \& John, 1999), how customer have value propositions by the product/service (Noseworthy \& Trudel, 2011), to keep customer top of mind about product/service (Ries and Trout, 2001). Many dimensions in positioning strategy. Arnott (1992, p. 111) with the famous concept of positioning (the deliberate, proactive, iterative process of defining, modifying and monitoring consumer perceptions of a marketable offering) proposed three related activities: (a) defining the dimensions of a particular perceptual space that adequately represents the target audience's perceptions, (b) measuring objects' locations within that space, and (c) modifying actual characteristics of the offering and perceptions of the target audience via marketing commu-nication strategies. Positioning efforts entail iterative processes that require the deliberate and proactive involvement of marketing managers. Another opinion that the essence of the positioning decision is the selection of the optimal mix of tangible and intangible offering attributes, pricing, distribution of consumer preferences, and positions of competitive offerings (Ansari, Economides, and Ghosh, 1994). The development of dimensions about the key positioning strategies for firms to pursue are service reliability, social responsibility, branding, top of the range, value for money, attractiveness, country of origin, and safety, which can enhance long-term competitive advantage (Aaker \&Shansby, 1982; Ries \& Trout, 2001; Hooley \& Greenley,2005; Fuchs \& Diamantopoulos, 2010; Coffie, 2018). Author see that these fundamentals are the most important things to make formulate and execute. Positioning Strategy is a strategy which tries to make a unique differentiation in the target customer's mind, so that it creates a brand image or product which is superior to the competitors' brand/product. There are seven approaches we can use for positioning, i.e. :

1. Positioning based on attributes, characteristics or benefits for customers (attribute positioning), by associating a product to certain attributes, special characteristics, or to the benefit for customers. Selecting attribute as the base of positioning should be based on seven criteria as follows:

- Importance, meaning that the attribute is very valuable in the perspective of most customers.

- Distinctiveness, meaning that the attribute is not offered by other companies. Alternatively, the attribute may be packaged by the company more clearly than its competitors. 
- Superiority, meaning that the attribute is superior to the other ways to get the same benefit.

- Communicability, meaning that the attribute can be communicated in a simple and clear way so that the customers understand it.

- Preemptive, meaning that the attribute can be imitated by competitors.

- Affordability, meaning that the target customers will be able to pay the difference or uniqueness of the attribute. Every additional cost for the special characteristic is considered equal to the added value.

- Profitability, meaning that the company is able to get additional profit by emphasizing the difference.

The main goal of an enterprise is to make profit that can maximize the value of company. Therefore, a company will try to implement effective and efficient strategies. In order to achieve this goal, the company needs not only customer's trust. It is impossible to reach this goal without any purchase decision made by consumers. To buy or not to buy, buy in a little quantity or buy in a big quantity, buy now or buy later or some day, and so on are possiblilty of customer's decisions. Many things can be considered as the bases of the decision: buying for brand, price, need, benefit, product attribute, and so on. These different considerations have different backgrounds, one of them is the social economic condition related to lifestyle. The decision making process by consumers can also be seen in a term of reference framework with a five-step model as follows (Kotler and Keller, 2006 p. 235):

- Problem identification

Purchase process begins when the buyer identifies the problem or need. The need can be triggered by internal and external stimulus.

- Information seeking

The consumers who are stimulated by their needs will be motivated to seek more information. This stimulus can be divided into two levels: the situation of lighter information seeking called attention strengthening, and the next level is active information seeking.

- Alternative Evaluation

Consumers regard each product as a set of attributes with different abilities in giving benefits that are used to fulfill the need. Consumers will pay much attention to the attribute that give the benefit they seek.

- Purchase Decision

In the evaluaion stage, consumers make a preference of brands which are available in the set of choice. They can also make intention to buy the brand they like the most. In actualizing the buying intention, consumers can take some sub-decisions: brand, dealer, quantity, time and payment method.

- $\quad$ Post-purchase Behaviour

After the purchase, consumers may experience inexpediency regarding certain features that are disrupting or because of hearing favorable things about other brand, and they will always be alert for the information that supports their decision. Marketing communication should provide confidence and evaluation which assert the consumers' choice and help them to feel comfortable with the brand.

Importance is closely related to the customer purchase decision because consumers or customers need the good or service to fulfill their living need. Whereas one of the orientations addressed by the company is the fulfillment of consumers' needs. Therefore, a hypothesis can be made that there is a significant relationship between importance and customer purchase decision. Product attributes must be made in a simple way so that the consumers can understand the benefit of the product. Product should also be communicable clearly both of physical and non-physical attributes so that it can fulfill customer expectation and be agreed by the consumers when they buy it. Therefore, the second hypothesis is that there is a significant relationship between the attribute of communicability and the customer purchase decision. Every consumer will take into account the cost of product or the service they need, as well as additional cost, and will also take into account the location to obtain 
the product or service whether they can afford it. Thus, the last hypothesis is that there is a siginificant relationship between affordability and the customer purchase decision.

\section{RESEARCH METHOD}

The method used in this research is exploratory research. This type of research is quantitative descriptive research. The respondents are customer on Starbucks Rest Area KM.19. The reasons for selecting customer Starbuck is based on the observation that the outlet Starbuck KM 19 is one of the most in demand by highway users. The population in this study is the consumer / customer Starbucks Rest Area KM.19 resting and drinking coffee, to improve fitness before traveling or going back to work area industrial area of West Java, Indonesia. Another reason of the research because Indonesia during 10 year ago until now have been have fashion of coffee. This tendency not only as coffee drinker but also as coffee resembling (kopistory, 2016). The tradition of a cup of coffee had move from the healthy body to life style of city society. The people make the tradition as drink coffee as the facility and comunication to meet the family, business partners, or reunion. Many exclusive place in Jakarta with the high end ambiance for the customers. In this research, the author want to know about the internal strategy of Starbucks and will impact to place of rest area attractivenes. Starbucks have eight outlet of rest area toll road and two outlets in rest area in west Java. One in 19 kilometers rest area and the other in 97 kilometers rest area. The concept that the starbucks deliver are drive-in and resto with the mall or office looks like. The high end services as the main outlet strategy. Authors saw that the population is a collection of individuals who have the qualities and traits that have been set. Based on the quality and characteristics of the population can be understood as a group of individuals or objects of observation that has at least one common characteristic (Cooper and Emory, 1995). To determine the indicators from theory into variable size, the researchers made a Focus Group Discussion (FGD) with some consumers selected. Even this research, including research design conclusive. The main aim conclusive studies to test hypotheses and certain specific relationships. Conclusive research consists of two kinds, namely descriptive and causal. This study was a causal research. Due to the location of the outlet is in the Starbuck rest area Cikampek KM 19, the number of population can not be known. If the population is not known, a minimum sample of 100 respondents (Cooper and Schindler, 2014 p 465). In 1975 Roscoe (1975) proposed a number of rules of thumb that can be used to select an appropriate sample for behavioral research. The range sampling from 30 to 500 responden (Sekaran, 2013). In this research, researchers set the number of samples that will be used by 100 respondents . The sampling technique used by the author is using a convenience sampling, where researchers have the freedom to choose whom to invite. Invitations distributed through the Send Short Message (SMS) based on data based on Starbucks Rest Area Km 19. They are the respondents listed as the consumer remains Starbucks Rest Area KM.19 and have provided the data to the management Starbuck Rest Area Km 19 West Java, Indonesia. Research variable is something that varies. The variation of variable is differentiated as follows:

- Dependent variable in this study is Purchase Decision (Y)

- Independent variable in this study is the Positioning of product attribute (X) and the elements of independent variable in this study are:

- Importance (X1)

- Communicability (X2)

- Affordability (X3)

\section{Operational Definition of Variable}

\begin{tabular}{l|l|l}
\multicolumn{1}{c|}{ Variable } & \multicolumn{1}{|c|}{ Definition } & \multicolumn{1}{c}{ Indicator } \\
\hline $\begin{array}{l}\text { Purchase } \\
\text { decision }\end{array}$ & $\begin{array}{l}\text { Real action performed by } \\
\text { consumers }\end{array}$ & $\begin{array}{l}\text { a. Purchase priority on certain } \\
\text { product }\end{array}$
\end{tabular}

https://ijstm.inarah.co.id 


\begin{tabular}{l|l|l} 
& & $\begin{array}{l}\text { b. Intention to buy the } \\
\text { product } \\
\text { c. Decision to buy the product }\end{array}$ \\
\hline Importance & $\begin{array}{l}\text { The importance degree of product } \\
\text { in fulfilling the need. }\end{array}$ & $\begin{array}{l}\text { a. How important to do the } \\
\text { product purchase. } \\
\text { b. The existence of product } \\
\text { that is always considered } \\
\text { important. }\end{array}$ \\
\hline Communicability & $\begin{array}{l}\text { How the company communicate } \\
\text { its product to consumers. }\end{array}$ & $\begin{array}{l}\text { a. The availability of information } \\
\text { from the company. } \\
\text { b. Information seeking by } \\
\text { consumers. }\end{array}$ \\
\hline Affordability & How far consumers can afford. & $\begin{array}{l}\text { a. The position of Starbucks outlet } \\
\text { b. Problem of price. }\end{array}$ \\
\hline
\end{tabular}

From the operational variables that have been mentioned, the author conditions the inter variables relationship proportionally. By this way, it is expected to obtain a confidence that can be considered as correct and a logic consequence. Before performing tests using the existing facts, a research framework will be made.

CONCEPTUAL MAPPING

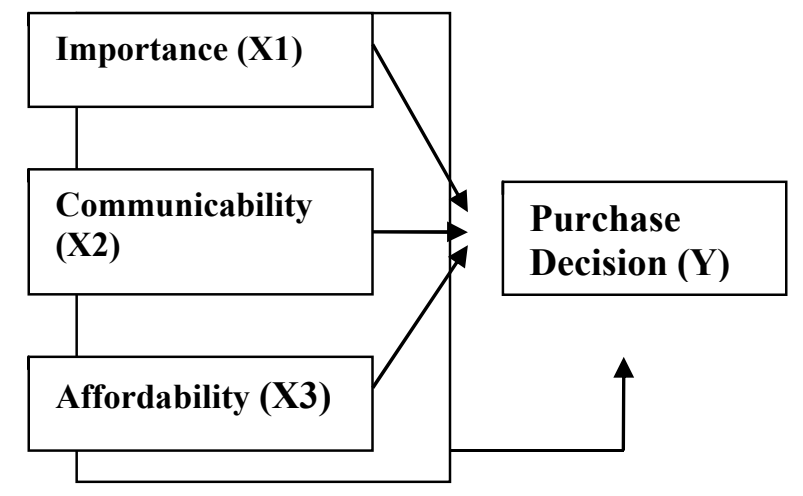

Fig 1. Research model

\section{DISCUSSION}

The respondents of this research are the consumers of Starbucks Coffee in KM 19 Rest Area Toll Cikampek. Data collection is done on weekends which coincide with national and religious holidays. The author meets as many as 100 people during the research. There are five characteristics of the respondents included in the research, namely sex/gender, age, education, occupation, and monthly expense.

The Characteristics of Respondents Based on Sex 


\begin{tabular}{l|c|c} 
Sex & $\begin{array}{c}\text { Frequency } \\
\text { (people) }\end{array}$ & Percentage (\%) \\
\hline Male & 56 & 56 \\
\hline Female & 44 & 44 \\
\hline Total & 100 & 100
\end{tabular}

Source: Primary Data, 2017

The description of respondent's identity based on sex indicates that male respondents are as many as 56 people (56\%) and female respondents are 44 people or $44 \%$. The figure illustrates that the consumers of Starbucks in KM 19 rest area are still dominated by male people but the spread between male and female respondents is not too much. From the interview with a number of female respondents regarding the effect of coffee, it is known that the reason is many women are getting better in understanding the positive effect of consuming coffee. So far, the opinion built by some people, especially women, considers cafein is not good to be consumed by women excessively.

\section{The Characteristics of Respondents Based on Age}

\begin{tabular}{c|c|c} 
Age & $\begin{array}{c}\text { Frequency } \\
\text { (people) }\end{array}$ & $\begin{array}{c}\text { Percentage } \\
\mathbf{( \% )}\end{array}$ \\
\hline$<20$ years & 9 & 9 \\
\hline 20-25 years & 18 & 18 \\
\hline 26-30 years & 25 & 25 \\
\hline 31-40 years & 33 & 33 \\
\hline 40 years & 15 & 15 \\
\hline Total & 100 & 100
\end{tabular}

Source: Primary Data,

2017.

Most customers or consumers who buy the product are those around the age of 31-40 years old. This data shows that the visitors of Starbucks KM19 are dominated by adults, both in group and family.

\section{The Characteristics of Respondents Based on Occupation}

\begin{tabular}{l|c|c} 
Occupation & $\begin{array}{c}\text { Frequency } \\
\text { (people) }\end{array}$ & $\begin{array}{c}\text { Percentage } \\
\text { (\%) }\end{array}$ \\
\hline Entrepreneur & 10 & 10 \\
\hline Housewife & 7 & 7 \\
\hline Civil Servant & 12 & 12 \\
\hline $\begin{array}{l}\text { Private } \\
\text { Employee }\end{array}$ & 34 & 34 \\
\hline $\begin{array}{l}\text { University } \\
\text { Student }\end{array}$ & 22 & 22 \\
\hline Others & 15 & 15 \\
\hline \multicolumn{2}{|c}{} \\
\cline { 2 - 3 }
\end{tabular}


\begin{tabular}{l|l|l} 
Total & $100 \quad 100$
\end{tabular}

Source: Primary Data, 2017

This data proves that Starbucks is well-known by respondents with various characteristics based on occupation, and not stick to a certain group.

The Characteristics of Respondents Based on

the Last Education

\begin{tabular}{l|c|c}
\multicolumn{1}{c|}{ Education } & $\begin{array}{c}\text { Frequency } \\
\text { (people) }\end{array}$ & $\begin{array}{c}\text { Percentage } \\
\text { (\%) }\end{array}$ \\
\hline Elementary School & 0 & 0 \\
\hline Junior High School & 0 & 0 \\
\hline Senior High School & 20 & 20 \\
\hline Diploma & 7 & 7 \\
\hline Bachelor & 60 & 60 \\
\hline Postgraduate & 13 & 13 \\
\hline Total & 100 & 100
\end{tabular}

Source: Primary Data, 2017.

From the tabulation above and the observation during research, an assumption can be made that some of Starbucks visitors are included in the category of established and well-educated.

The Characteristics of Respondents Based on

Monthly Expense

\begin{tabular}{c|c|c}
$\begin{array}{c}\text { Monthly Expense } \\
\text { (IDR) }\end{array}$ & $\begin{array}{c}\text { Frequency } \\
\text { (people) }\end{array}$ & $\begin{array}{c}\text { Percentage } \\
(\mathbf{\% )})\end{array}$ \\
\hline$<1$ million & 5 & 5 \\
\hline 1 million -2 million & 15 & 15 \\
\hline 2 million -4 million & 44 & 44 \\
\hline 4 million -6 million & 30 & 30 \\
\hline$>6$ million & 6 & 6 \\
\hline Total & 100 & 100
\end{tabular}

Source: Primary Data, 2017

What is interesting from this data is that the respondents with monthly expense around Rp 2-6 million are as many as 74 people or $74 \%$. The high price of a cup of Starbucks coffee makes a limitation of the segment of Starbuck visitors.

\section{Descriptive Analysis on the Variable of Importance}

Descriptive analysis on the variable of importance is based on the respondents' answers to the questions listed in the questionnaire distributed to the respondents. The variation of respondents' answers for the variable of importance can be seen in Table 4.6 below:

The Frequency of Answer on the Variable of Importance (X1)

\begin{tabular}{lrrrrrrl}
\hline \hline Question/Indicator & STS & TS & KS & S & SS & Index & Conclusion \\
& 1 & 2 & 3 & 4 & 5 & Value & \\
\hline $\begin{array}{l}\text { 1. Buying some drink in Starbucks } \\
\text { becomes an important thing in }\end{array}$ & 5 & 7 & 56 & 31 & 1 & 316 & Fair \\
& & & & & & &
\end{tabular}


your daily life.

$\begin{array}{llllllll}\text { 2. In every trip passing through the toll } & 9 & 8 & 42 & 41 & 0 & 315 & \text { Fair }\end{array}$

of Cikampek, stop at Starbucks

KM 19 is the thing you always do.

3. In your opinion, one of the goods $\quad \begin{array}{llllllll}1 & 6 & 10 & 55 & 28 & 403 & \text { Fair }\end{array}$

In the form of food is coffee.

4. You always remember certain

$\begin{array}{lllllll}5 & 3 & 4 & 53 & 35 & 412 & \text { Fair }\end{array}$

products of Starbucks KM 19

Source: Questionnaire data processing, 2017

Descriptive Analysis on the Variable of Communicability

Descriptive analysis on the variable of communicability is based on the respondents' answers to the questions listed in the questionnaire distributed to the respondents. The variation of respondents' answers for the variable of communicability can be seen in Table 4.7 below:

Table 4.7 The Frequency of Answer on the Variable of Communicability (X2)

\begin{tabular}{|c|c|c|c|c|c|c|c|}
\hline Question/Indicator & $\begin{array}{c}\text { STS } \\
1\end{array}$ & $\begin{array}{r}\mathrm{TS} \\
2\end{array}$ & $\begin{array}{r}\mathrm{KS} \\
3\end{array}$ & $\begin{array}{l}S \\
4\end{array}$ & $\begin{array}{l}\text { SS } \\
5\end{array}$ & $\begin{array}{l}\text { Index } \\
\text { Value }\end{array}$ & Conclusion \\
\hline $\begin{array}{l}\text { 1. In buying the product of Starbucks, } \\
\text { do you need information from Barista } \\
\text { (a coffee maker). }\end{array}$ & 1 & 6 & 25 & 50 & 18 & 378 & High \\
\hline $\begin{array}{l}\text { 2. Information on the kinds of drink } \\
\text { that can be chosen in Starbucks KM } 19 \\
\text { is available. }\end{array}$ & 2 & 4 & 41 & 51 & 2 & 347 & High \\
\hline 3. Are new menu always available & 1 & 7 & 3 & 44 & 45 & 425 & High \\
\hline
\end{tabular}

\section{Descriptive Analysis on the Variable of Affordability}

Descriptive analysis on the variable of affordability is based on the respondents' answers to the questions listed in the questionnaire distributed to the respondents. The variation of respondents' answers for the variable of affordability can be seen in Table 4.8 below:

Table 4.8 The Frequency of Answer on the Variable of Affordability (X3)

\begin{tabular}{lrrrrrll}
\hline \hline Question/Indicator & STS & TS & KS & S & SS & Index & Conclusion \\
& 1 & 2 & 3 & 4 & 5 & Value & \\
\hline 1. According to you, the location of & 2 & 5 & 7 & 45 & 41 & 418 & High
\end{tabular}

Starbucks should be in front of the entrance.

$\begin{array}{lllllllll}\text { 2. Do you mind to pay the parking fee? } & 1 & 9 & 18 & 63 & 9 & 370 & \text { High }\end{array}$

3. Do you have problem with the price? $\quad \begin{array}{lllllllll} & 4 & 32 & 57 & 4 & 354 & \text { High }\end{array}$

4. Are you interested in the cooperation $11 \quad 2 \quad 23 \quad 50 \quad 24 \quad 395 \quad$ High

program with certain merchants.

Source: Questionnaire data processing, 2017

Descriptive Analysis on the Variable of Purchase Decision 
Descriptive analysis on the variable of purchase decision is based on the respondents' answers to the questions listed in the questionnaire distributed to the respondents. The variation of respondents' answers for the variable of purchase decision can be seen in Table 4.9 below:

Table 4.9 The Frequency of Answer on the Variable of Purchase Decision (Y)

\begin{tabular}{lccccccc}
\hline \hline Question/Indicator & STS & TS & KS & S & SS & Index & Conclusion \\
& 1 & 2 & 3 & 4 & 5 & Value & \\
\hline $\begin{array}{l}\text { 1. I do not take into account alternative } \\
\text { brands of coffee shop or other outlets }\end{array}$ & 2 & 7 & 48 & 42 & 1 & 345 & High \\
$\quad$ in the Rest Area KM 19 when I decide & & & & & & & \\
$\quad \begin{array}{l}\text { to buy the product of Starbucks. } \\
\text { 2. Many choices of promotion offered }\end{array}$ & 2 & 10 & 20 & 63 & 5 & 378 & High \\
3. I do purchasing product because of & 5 & 8 & 9 & 51 & 27 & 401 & High \\
$\quad$ Starbucks' popularity. & & & & & & & \\
\hline
\end{tabular}

Source: Questionnaire data processing, 2017

\section{Validity Test}

The result of validity test through SPSS 21.00 program using the Pearson formula (correlation product moment) against the research instrument finds the correlation figures as described in the following table.

Table 4.10 Result of Validity Test

\begin{tabular}{|c|c|c|c|c|c|}
\hline Variable & $\begin{array}{l}\text { Item/ } \\
\text { Code }\end{array}$ & $\begin{array}{l}\text { Bivariate } \\
\text { Correlation }\end{array}$ & $\begin{array}{l}\text { Corrected Item } \\
\text { Total-Correction }\end{array}$ & $\begin{array}{c}\mathrm{r} \\
\text { Table }\end{array}$ & Remarks \\
\hline \multirow[t]{4}{*}{ Importance } & $\mathrm{X} 1.1$ & 0.686 & 0.580 & 0.532 & Valid \\
\hline & $\mathrm{X} 1.2$ & 0.655 & 0.518 & 0.532 & Valid \\
\hline & $\mathrm{X} 1.3$ & 0.685 & 0.567 & 0.532 & Valid \\
\hline & $\mathrm{X} 1.4$ & 0.628 & 0.476 & 0.532 & Valid \\
\hline \multirow[t]{3}{*}{ Communicability } & $\mathrm{X} 2.1$ & 0.764 & 0.639 & 0.532 & Valid \\
\hline & $\mathrm{X} 2.2$ & 0.670 & 0.543 & 0.532 & Valid \\
\hline & $\mathrm{X} 2.3$ & 0.827 & 0.722 & 0.532 & Valid \\
\hline \multirow[t]{4}{*}{ Affordability } & $\mathrm{X} 3.1$ & 0.765 & 0.661 & 0.532 & Valid \\
\hline & $\mathrm{X} 3.2$ & 0.662 & 0.547 & 0.532 & Valid \\
\hline & X3.3 & 0.646 & 0.527 & 0.532 & Valid \\
\hline & X3.4 & 0.722 & 0.623 & 0.532 & Valid \\
\hline Purchase & Y1 & 0.734 & 0.634 & 0.532 & Valid \\
\hline \multirow[t]{2}{*}{ Decision } & Y2 & 0.755 & 0.658 & 0.532 & Valid \\
\hline & Y3 & 0.886 & 0.801 & 0.532 & Valid \\
\hline
\end{tabular}

Source: Questionnaire data processing by SPSS 21.00, 2017

The result is obtained in two ways. The first is by using Pearson formula (bivariate correlation) and the second is from the total correlation on the reability analysis (Corrected Item-Total Correlation). Based on the table of validity test result above, it is known that all the questions used in this study is valid, indicated by each question whose value of correlation coefficient is positive and more than $r$ table.

\section{Reliability Test}

The reliability test gets the results as stated in the following table, using SPSS 21.00. 
Table 4.11 Reliability Test

\begin{tabular}{lccl}
\hline \hline Variable & Cronbach Alpha & Standard Value & Remarks \\
\hline Importance & 0.758 & $0.61-0.80$ & Reliable \\
Communicability & 0.806 & $0.61-0.80$ & Reliable \\
Afordability & 0.778 & $0.61-0.80$ & Reliable \\
Purchase Decision & 0.822 & $0.61-0.80$ & Reliable \\
\hline
\end{tabular}

Source: Questionnaire data processing by SPSS 21.00, 2017

The value of cronbach alpha of all the tested variables is $>0.60$ so that the indicator or questionnaire of the 706 five variables are reliable or deserve to be relied on as a variable measuring tool.

\section{Multilinear Regression Analysis}

\section{Multicorrelation Analysis (R)}

The result of regression between the positioning strategy of product attribute and the variables of importance, communicability and affordability against the purchase decision on the product of Starbucks KM 19 can be seen as follows.

\section{Table 4.12 Result of Multicorrelation \& Determination Analysis}

Model Summary b

\begin{tabular}{llllll}
\hline \hline Model & R & R Square & $\begin{array}{l}\text { Adjusted } \\
\text { R Square }\end{array}$ & $\begin{array}{l}\text { Std.Error of the } \\
\text { Estimate }\end{array}$ & $\begin{array}{l}\text { Durbin- } \\
\text { Watson }\end{array}$ \\
\hline 1 & $.639^{\mathrm{a}}$ & .408 & .390 & 1.572 & 1.778 \\
\hline
\end{tabular}

a. Predictors : (Constant), Affordability, Importance, Communicability

b. Dependent Variable: Purchase Decision

Source: Questionnaire data processing by SPSS 21.00, 2017

Based on the table above, $\mathrm{R}$ value is found 0.639. This indicates that there is a strong relationship between affordability, importance and communicability and purchase decision.

\section{Determination Analysis ( $\left.\mathbf{R}^{2}\right)$}

From the output of regression analysis as included in Table 4.12, the value of $\mathrm{R}^{2}$ ( $\mathrm{R}$ square) is found 0.408 or $40.8 \%$. This indicates that the influence of independent variables on the dependent variable is $40.8 \%$. Whereas the rest is influenced by other variables which are not included in this study.

\section{Simultaneous Test of Regression Coefficient (F test)}

From the output of regression analysis between the positioning strategy of product attribute and the variables of importance, communicability and affordability against the purchase decision on the product of Starbucks KM 19, the value of $\mathrm{F}$ is found as in Table 4.13 below:

Table 4.13 Simultaneous Test of Regression Coefficient (F test)

ANOVA $^{\mathrm{a}}$

\begin{tabular}{|c|c|c|c|c|c|c|}
\hline & Model & Sum of Squares & $\mathrm{df}$ & Mean Square & $\bar{F}$ & Sig. \\
\hline \multirow{3}{*}{1} & Regression & 163.638 & 3 & 54.546 & 22.084 & $.000 \mathrm{~b}$ \\
\hline & Residual & 237.112 & 96 & 2.470 & & \\
\hline & Total & 400.750 & 99 & & & \\
\hline
\end{tabular}

a. Dependent Variabel: Purchase Decision

b. Predictors: (Constant), Affordability, Importance, Communicability 
Source: Data processing by SPSS 21.00, 201

Based on Table 4.13, F calculation is found 22.084. Using the confidence level of $95 \%$, a $=5 \%$, df $1=$ number of variables $-1=4-1=3$, df $2=n-k-1=14-3-1=10$, the value of $F$ table is 3.71 . Since $F$ calculation $>\mathrm{F}$ table $(22.084>3.71)$, then Ho is rejected. It means there is a significant influence of the variables of importance, communicability and affordability on purchase decision.

\section{Partial Test of Regression Coefficient ( $t$ test)}

From the output of regression analysis between the positioning strategy of product attribute and the variables of importance, communicability and affordability against the purchase decision on the product of Starbucks KM 19, the value of $t$ is found as in Table 4.14 below:

\section{Table 4.14 Result of Partial Test of Regression Coefficient (t test)}

Coefficients $^{\mathrm{a}}$

Coefficients $^{\mathrm{a}}$

\begin{tabular}{|c|c|c|c|c|c|c|c|}
\hline \multirow[t]{2}{*}{ Model } & \multicolumn{2}{|c|}{$\begin{array}{l}\text { Unstandardized } \\
\text { Coefficients }\end{array}$} & $\begin{array}{l}\text { Standardized } \\
\text { Coefficients }\end{array}$ & \multirow[t]{2}{*}{$\mathrm{t}$} & \multirow[t]{2}{*}{ Sig. } & \multirow{2}{*}{$\begin{array}{l}\text { Collinearity } \\
\frac{\text { Statistic }}{\text { Tolerance }}\end{array}$} & \multirow{2}{*}{ VIF } \\
\hline & B & Std.Error & Beta & & & & \\
\hline (Constant) & 1.823 & 1.139 & & 1.600 & .113 & $\cdot$ & \\
\hline Importance & .295 & .114 & .338 & 2.594 & .011 & .362 & 2.760 \\
\hline $\begin{array}{l}1 \text { Communi- } \\
\text { cability }\end{array}$ & .184 & .143 & .170 & 1.291 & .200 & .356 & 2.810 \\
\hline Affordability & .172 & .098 & .199 & 1.752 & .083 & .480 & 2.084 \\
\hline
\end{tabular}

a. Dependent Variable: Purchase Decision

Source: Data processing by SPSS 21.00, 2017

The distribution table $\mathrm{t}$ is found at $\mathrm{a}=5 \%: 2=2.5 \%$ (2-sided test) with degree of freedom $(\mathrm{df})=\mathrm{n}-\mathrm{k}-1$, where $\mathrm{n}$ is the number of question items in the questionnaire and $\mathrm{k}$ is the number of independent variables. Thus, distribution table $\mathrm{t}$ can be obtained from $\mathrm{df}=14-3-1=10$, the result for $\mathrm{t}$ table is 2.228 .

The criteria for testing:

- If $\mathrm{t}$ calculation $>\mathrm{t}$ table, it is concluded that the variable has significant influence.

- If $\mathrm{t}$ calculation $<\mathrm{t}$ table, it is concluded that the variable does not have significant influence.

The following is the result of $t$ test on each independent variable:

- The variable of Importance (X1)

The value of $t$ calculation for this independent variable is 2.594 . Whereas the value in the distribution table of $5 \%$ is 2.228 . So, $t$ calculation (2.594) $>\mathrm{t}$ table (2.228) meaning that the variable of importance partially has significant influence on purchase decision.

- The variable of Communicability (X2)

The value of $t$ calculation for this independent variable is 1.291 . Whereas the value in the distribution table of $5 \%$ is 2.228 . So, $t$ calculation $(1.291)<t$ table $(2.228)$ meaning that the variable of communicability does not have significant influence on purchase decision.

- The variable of Affordability (X3)

The value of $t$ calculation for this independent variable is 1.752 . Whereas the value in the distribution table of $5 \%$ is 2.228 . So, $t$ calculation $(1.752)<t$ table $(2.228)$ meaning that the variable of affordability does not have significant influence on purchase decision.

The strength of a brand is not coming out of the organization, but the organization's strengths come from the brand of a product. Brand products can be strong and well known in the community because these products can

\section{https://ijstm.inarah.co.id}


show you personally figure suitable products with consumers so that the name of an organization's brand manufacturers of these products have no effect. When a strong brand and the product becomes known in the community then the producer organization company that will be more famous and known for their product brands. A market leader will not allow competitors to act radically to become number one. Careful market leader will soon be shut down land marketing their products. Even closing with a wide range of brand new, to face competitors. With this technique, then consumers will be confused because many brands of choice in a category that should be chosen.

By using SPSS 21.00 through the $t$ test it is known that the importance variables have a significant influence on purchasing decisions by customers with the results of $t$ count $>t$ table. Meanwhile, two other variables, namely the communicability and affordability variables, do not have a significant effect on purchasing decisions. However, using multiple correlation analysis, the three variables, namely the importance variable, the communicability variable and the affordability variable greatly influence the purchase decision. This is shown by the multiple correlation analysis test that the R number is 0.639 .

In line with Kurniawati's research (2010) that in order to produce a purchase decision, consumers usually go through the stage of problem recognition, information search, evaluation of alternatives after which they can produce a purchase decision. The responses given can come from direct experience which is an important characteristic of a purchasing decision.

\section{REFERENCES}

[1] Cooper D R and Schindler P S, 2014, Business Research Methods, Twelfth Edition, Mc Graw Hill International Edition, New York.

[2] Kartajaya,Hermawan, 2004, On Becoming the marketing company, Penerbit PT Gramedia Pustaka Utama, Jakarta. Termuat di : books.google.co.id/books?isbn=9792208046 di akses pada 22 Juli 2015

[3] Krejcie \& Morgan (1970) Determining Sample Size for Research Activities. Retrieved August 28. 2015 From: http://people.usd.edu/ mbaron/edad810/Krejcie.pdf

[4] Kotler, Philip \& Keller, Kevin Lane, 2008, Marketing Management (Edisi Bahasa Indonesia), PT.Indeks.

[5] Kurniawati T A, 2010, Pengaruh Variabel Produk, Harga, Lokasi dan Promosi terhadap Keputusan Pembelian pada Rumah Makan Padang Sederhana di Kota Malang, Jurnal Ilmiah Bisnis dan Ekonomi Asia, Vol 5 No. 1 Desember 2010 diakses pada 25 September 2015.

[6] Muhidin S A dan Abdurahman M, 2009, Analisis Korelasi, Regresi dan Jalur dalam Penelitian (dilengkapi Aplikasi Program SPSS), Pustaka Setia.

[7] Mustain, Hasma Laely, 2012, Analisis Pengaruh Strategi Positioning Terhadap Keputusan Pembelian Pada Konsumen Starbucks Coffee di Makassar, Universitas Hasanuddin, Makassar. Retrieved July 12, 2015 From : URI: http://repository.unhas.ac.id/handle/123456789/1669

[8] Sugiyono, 2010, Metode Penelitian Kuantitatif, Kualitatif dan R\&D, Alafabeta. Sekaran U and Bougie R, 2013, Research Methods for Business : A Skill-Building Approach, $6^{\text {th }}$ Edition, John Willey \& Sons Corp.

[9] StatPac. (2012). Survey Sampling Methods. Retrieved August 28. 2015 From: http://www.statpac.com/surveys/sampling.htm

[10] Trachoma, William M.K. (2006). Sampling. Retrieved August 28.2015 From: "http://www.socialresearchmethods.net/kb/sampling.php

[11] Yuliana R, 2013, Analisis Strategi Pemasaran pada Produk Sepeda Motor Matik berupa Segmentasi, Targeting dan Positioning serta pengaruhnya terhadap Keputusan Pembelian Konsumen di Semarang, Jurnal STIE Semarang, VOL 5, NO 2, Edisi Juni 2013 (ISSN : 2252-7826) diakses pada 11 Oktober 2015 